\title{
Popular Darwinism and Geography Textbooks in Canada, 1850-1920
}

Eric Gormley

ABSTRACT: Influenced by Darwin's ideas, geographers in the late nineteenth century attempted to understand how the earth affected man. Disseminating their ideas through textbooks, geographers established what physical and climatic features were favourable for advancement and also defined what constituted progress or success. A dense population, for instance, was desirable, a sign the race was succeeding. This paper analyzes pre-and post-Darwinian geography textbooks used in the Canadian school system, indicating that they helped to shape culture at the turn of the century. Geography textbooks in Canadian schools were an important mechanism for the transmission of popular conceptions of Darwinian thought.

The second half of the nineteenth century was a period in which basic assumptions shared by Western man came under attack. Charles Lyell's work in geology began to revise men's and women's idea of the age of the earth, and Charles Darwin, Alfred Russell Wallace, and Herbert Spencer changed the way they looked at nature and themselves. These scholars threw into question the notion that God had created humans, suggesting instead that they had evolved from a primitive life form.

Canadian historians have most often treated the subject of natural selection in terms of how churchmen coped with its revolutionary implications, and indeed a considerable "sacred to secular" debate has been waged in the literature since the early 1970s. Little attention, however, has been given to the effect of these ideas on wider society, although Carl Berger has sketched out the impact of Darwin's theory of evolution by natural selection on the Canadian scientific community. Berger notes the leading natural ists' vehement opposition to natural selection, followed by the theory's gradual acceptance and transmission to students by the 1890s. Calling the theory "truly revolutionary," he states the "idea of evolution through natural selection had repercussions upon every aspect of man's selfunderstanding. "I If his view that Darwinian thought shook the very foundations of human thought holds true, then one expects to find a host of common beliefs undergoing change in this period. Ramsay Cook, for one, has shown how acceptance of the evolutionary model

Past Imperfect Vol. 2, 1993, pp. 87-106 
of progress led some churchmen away from worrying about the afterlife and towards finding solutions for immediate, earthly problems. ${ }^{2}$ This paper examines other areas of Canadian life influenced by Darwinian thought. It will focus on geography texts in the public schools, from mid-nineteenth century, a decade before Darwin published Origin of Species, to the 1920s. Geography is especially fit for the purposes of this study, since nature in all its manifestations was at the very centre of the Victorian mind, blending the religious and secular worlds. Starting from the assumption that God created the world as a setting for humans to work out their moral perfectibility, it was a short step for early Victorians to see land and natural resources as tools for reaching this end. Advances in civilization were signs of moral progress, since knowing of, and benefiting from, God's creation was the same as knowing Him.

Through the use of geography, elementary and secondary schools endeavoured to acquaint students with the natural world, including the diverse cultures of humankind. Geography offered perspective, helping students to define their country and place it within a larger world. Clearly though, the definition of the subject changed at the end of the nineteenth century. At mid-century most textbook authors, influenced by the religious ethos of the times, assumed geography to be a "description of the surface of the earth, with its inhabitants and productions," 3 essentially an account of what God had created. Later, once the earth and humans were thought to be older than the biblical estimate, once nature itself was seen as a lifedetermining mechanism, geographers were exhorted to know "land and sea, air and beast and tree," and "see how each controls the rest and how all work together." "Putting emphasis on natural, rather than heavenly, processes, one 1910 Canadian school text explained that geography was "the study of the earth and its relation to plants, animals and men that live on its surface."

The place of geography in nineteenth-century Canadian school curricula needs more research, but it appears to have grown in popularity from 1850 onwards. Alison Prentice found that "as early as 1850, an 'acquaintance' with English grammar along with geography was added to the knowledge of reading, writing and arithmeric formally required for admission into the provincial Normal School. ${ }^{\text {"6 }}$ Bruce Curtis's recent study of education in Canada West reveals that one-seventh of the 1850 pupil enrollment took geography, and the figure climbed to forty per cent by 1865 when it was studied by 
137,903 students. ${ }^{7}$ Meanwhile, British Columbia high schools offered "ancient and modern" geography in the 1870s, and between 1890 and 1905 the Alberta district obliged students to take geography in their first two years of high school. " $A$ great deal of the high school work in geography and history [in Alberta] was a review and continuation of work covered in the elementary school standard," notes Bernal Walker. "The aim apparently was to prepare high school students to teach geography and history in the elemencary schools."

Unfortunately, our knowledge of textbooks used in Canadian schools is less detailed than our knowledge of the curriculum. Bernard Amtmann's A Bibliography of Canadian Children's Books and Books for Young People 1841-1867shows that a number of geography textbooks were published in Montreal and Toronto in English and French, as well in the maritime colonies. ${ }^{10}$ Some were local in orientation, such as The Geography and History of Nova Scotia and Geography of Canada. Another title, suggesting a religious orientation, was $A$ catechism of Geography, being an easy introduction to the knowledge of the world and its in habitants. How many of these works found their way into schools is unclear. Curtis notes that British texts in the 1830s and 1840s were preferred over American books, and that a reprint of I rish textbooks was widely-used at mid-century. He also discovered that there was a "movement in the organizing principles in school knowledge away from sacred and directly religious literature towards 'science' and 'useful knowledge." The Irish series, states Curtis, "embodied the results of the 'natural theology' of the late eighteenth and early nineteenth centuries ..."11 In terms of this paper, the limited number of mid-century Canadian texts available requires that they be supplemented by American ones. $^{12}$ The reluctance of administrators to use American books in Canadian schools appeared to be based more on a fear of cultural invasion than on any real difference in how the two countries viewed God and nature. American geography textbooks, as is argued below, were influenced by natural theology, an approach, Curtis finds, that was gaining popularity among Canadian educators at mid-century. Brian McKillop concurs, summarizing the views of William Paley, the originator of natural theology, as "everywhere in nature there is design [and]... there cannot be design without a designer." McKillop argues that at "Anglo-Canadian universities ... for during much of the nineteenth century, a Paleyite natural theology served as a staple in the academic diet." ${ }^{13}$ As for American literature, despite the 
apparent surfeit of Canadian publications, school trustees in Canada West did authorize the use of at least one American geography text in the 1850 s. $^{14}$

In the United States geography enjoyed a similar rise in popularity at mid-century. Charles Dryer wrote at this time that "many new textbooks of geography for various grades of the common school began to appear, of which those of Colton, Cornell, Mitchell, Monteith and Warren were the most popular." A turn-of-thecentury author of geography textbooks, Dryer observed that few instructors went beyond what the texts offered and thus the texts provide a reasonable approximation of what was being studied in the classroom. ${ }^{15}$

Until 1890, geography textbooks in Canada and the United States largely reflected a Christian view of the world. Dryer confirmed the influence of natural theology in early American geography textbooks when he wrote, rather condescendingly, in 1924 that "the appeal was largely to the sense of wonder and awe. There was little or no attempt at scientific explanation, but frequent references to the power, wisdom and goodness of the Creator ... [The texts] seemed designed as much for religious as for scientific education."16 Remarks, such as Roswell Smith's "the Heavens and the Earth are Full of thy Wonderous Works $O$ Lord," and James Monteith's "flowers ... by their bright looks and sweet odors express their joy and thankfulness to God," support Dryer's contention. ${ }^{17}$ The desired object was to find good in even the most trying of natural conditions. Storms "purify" the air, and "rugged mountains ... appear[ing] like deformities ... are found to serve important purposes, by the care of Him who made them," such as condensing vapours and helping to cool the earth's temperature. ${ }^{18}$ When it came to humans, though, geographers went beyond mere description. Although controversy surrounded the idea, geographers held that humans were created of one blood, or family, usually in south-western Asia and from there spread across the world. ${ }^{19}$ Differences in skin colour and the state of civilization were attributed to "a difference in climate, food and mode of life, and no doubt partly to causes we do not understand." ${ }^{20}$ A hot climate, went the reasoning, produced thick, tangled vegetation, hindering agriculture and anything but the rudest human settlements. Conversely, upland, temperate climates promoted co-operative human endeavour. Thus, we learn from Cornell's High School Geography (New York, 1857) that some of the native tribes of Bolivia were intelligent and 
industrious while others remained in a "savage" state. ${ }^{21}$ This scheme implies the plasticity of humans, but adaptation was not a theme geographers enunciated until the 1880 s. Although race had many practical implications for mid-century Americans, texts published in the northern states ignored the slavery question and only briefly mentioned blacks in their regional descriptions. In a separate section, though, they divided the human races by skin colour - European, Chinese, Malay, Indian [red], and African - ranked them according to their state of civilization - civilized, half-civilized, barbarous, and savage - and distinguished them by their proficiency at farming, manufacturing, and commerce. The "civilized" nations, as expected, were adept at these vocations; they also built "cities and towns" and formed governments that "did not oppress the people." ${ }^{22}$ Cornell's High School Geography described the half-civilized's (normally the Mongolian) knowledge of "arts and science and agriculture" as "very imperfect," and of commerce, as "exceedingly limited," while their manufactured goods were "few and of an inferior order." ${ }^{23}$ Nevertheless, William Swinton's Introductory Geography in Readings and Recitations (New York, 1882) reported the half-civilized "seem to be on the way to becoming civilized."24

The rexts left no question that whites were superior, but they were not rigorously ethnocentric in tone. Roswell Smith (New York, 1852) described the Chinese as an "ingenious people" and many authors praised the Japanese for adopting railways and a telegraph system. ${ }^{25}$ Improvement was usually linked to Christianity. Augustus Mitchell's school text, $A$ System of Modern Geography (Philadelphia, 1852), proclaimed "The Christian nations are much superior in knowledge and power to all others ... and through the increase of their colonies, the influence of the press, and the exertions of missionaries will no doubt ... spread their religion over the greatest part of the earth. ${ }^{26}$ Softening its language a little, the 1878 edition described the African Hottentots as a "low and brutish race," but improved since Protestant missionaries began to live among them. ${ }^{27}$ Meanwhile, Smith wrote that "by the exertions of Christian missionaries many [of the Malay race] have been induced to abandon their barbarous customs, and adopt the usages of civilized life. ${ }^{28}$ The same sentiments are found in 1880s Canadian books which promise, "when colonization and the labours of missionaries shall have more fully opened up the continent and civilized its people, Africa will take its place as one the most progressive regions of the world. ${ }^{29}$ Trade 
and commerce were also agents of civilization. High School Geography (Toronto, 1887) stated for example, "the Congo Free State will carry trade, and with it civilization and Christianity to the very heart of the continent." The benevolent tone of this mission is contained in the book's peroration on the subject: "the vigorous civilizations of western Europe, particularly that of the Anglo-Saxon type is spreading far and wide over the world, not only in the colonies, but in the homes of the more ancient civilizations ... thus repaying these countries for what it itself owes them. ${ }^{-31}$

Altogether, geography textbooks from the 1850 s through to the 1880 s displayed a liberal, Christian viewpoint: civilization was built on the cornerstones of agriculture, industry, commerce, and religion, and all the world deserved to have it. From the mid-1880s onwards, however, key changes crept into textbooks. High School Geography admitted "the existence of man on the earth dates from a period indefinitely remote," ${ }^{32}$ and in Eclectic Physical Geography (New York, 1888) Russell Hinman announced, "whatever may have been the origin of man, and whatever may be his true relationship to the higher animals he so closely resembles[,] [we know he has been on earth for] ... possibly hundreds of thousands of years. ${ }^{33}$ Describing Hinman's book as "ten years ahead of its time," Dryer observed that Hinman "presented boldly and for the first time to American high school students, the doctrines of Darwin and Huxley, heredity, variation, adaptation, environment, selection, evolution." In the chapter on man, moreover, Hinman addressed natural selection directly, illustrating the similarities between man and the apes, and argued the probability that humans descended from the apes. Hinman's work was well received and became the standard text for ten years. ${ }^{34}$ Underscoring the tension in Eclectic Physical Geography and other texts written in this transitional period is Hinman's inclusion of a biblical quocation before each chapter and a concluding sentence counselling "reverence for the Divine Wisdom which devised [the world] and which maintains it all." 3

Despite such acknowledgment, reference to God had all but passed from the pages of geography rextbooks by 1900 . The new geography that arose in its place combined Lyell's ideas about the age of the earth and Darwin's principle of natural selection with Thomas Huxley's notions of physiography. Physiography's major principle was a changing physical world, primarily caused by erosion. "Nothing in nature is permanent," wrote Hinman, departing from the 
received version. ${ }^{36}$ Leading proponents of this school included Albert Perry Brigham, a Professor of Geology at Colgate University, and Grove Karl Gilbert, a geologist with the United States Geological Survey. They published a high school textbook which was revised and appeared as Ontario High School Physical Geography in 1909, its success prompting a second Canadian edition in 1914. Like Hinman they declared, "there was a time when man thought of the earth as unchanging, but the geographer no longer speaks of the "everlasting hills ... [7] ime is long, and all the storms of thousands of centuries can even remove hills." ${ }^{37}$ Especially salient in their work is the idea that change in the earth had the effect of "modifying or controlling climate, organic distribution, and the history of man." 38

Physical geography raised what previously had been an informational subject to a science of the processes of change in the natural environment. Its importance lay in the belief that changes in natural environment helped drive the evolutionary process, since, as Darwin suggested, "geology plainly proclaims that each land has undergone great physical changes, [and thus] we might ... expect ... to find that organic beings have varied under nature..." Extending his hand even further to geographers he asked, "why under changing and complex conditions of life should not variations useful to nature's living products also arise?" 39 Mirroring Darwin's disbeliefin the "creation" of species, geographers, too, began to see life as a function of the natural world. The position or role of humans vis-à-vis nature was more ambiguous. Some contemporaries believed "that man's meteoric intelligence had liberated him from the cramping organic law of natural selection" and that humans could intervene directly in the evolutionary process. ${ }^{40}$ Part of the attraction of physical geography was indeed coming to understand the forces of nature with the object of controlling them. Escaping from the forces of nature may, however, have been merely wishful thinking. The Public School Geography (Toronto, 1900) spoke of "history, customs, industry and commercial relations ... [being] modified by the forces of nature," ${ }^{41}$ and Dominion School Geography (Toronto, 1910) conceded that humans might be able to alter land and distribution of water, but that they had little control over climate. ${ }^{42}$

Despite the rise of physical geography, many Canadian textbooks at the turn of the century continued to describe the countries of the world, their physical features, industries, and people. If the authors believed that humans were exempt from the laws of natural selection 
- "survival of the fittest" - these texts hardly showed it. Geographers adopted new yardsticks to measure the success of peoples; no longer was command of the arts and sciences and knowledge of religion enough: they looked at soil, vegetation, climate, and other natural phenomena, humans included. Civilization was admirable, but now more than ever they feared it could be fleeting.

Variation was a key part in Darwin's evolutionary mechanism, and Canadian geography textbooks alluded to it under a number of headings. Darwin was never able to account for variation in species, whether it occurred by chance or was governed by unknown natural laws, but constant, slight changes in organisms formed the centerpiece of his theory. Its implication for species was clear: change or die out. Thus, finding ways to direct the course of human evolution seemed almost less urgent for late Victorians than simply ensuring change occurred at all. As humans were distinguished for their mental power, enhancing this faculty gained in import. A country's provision for formal education was routinely commented on in turnof-the-century textbooks, with High School Geography finding that "education is liberally provided for by the local government in all the provinces," 43 and Dominion School Geography praising the Scots for their zealousness in "religion and education" and Germans for their "excellent system of compulsory education." 44 "If educating its people is the surest way a country can advance," went another, "then the future of Bolivia is secure."45 This view of education was still current in 1922 when Canadian School Geographydescribed Ontarians as "well educated." 46 Significantly few discussed what was being taught; most writers were content that a system existed at all. Hinman suggested that education's main purpose was to activate the mind. He wrote that "through their continual use or exercise[,] man's mental powers have gradually increased." 77 Increasing mental capacity was a form, albeit a self-directed one, of changing or varying humans.

Geographers thought the physical outline of a continent was another factor in change. Writers point to the length of Europe's coastline to explain why it had progressed where others had not. "There is no wonder that its people have taken such a place in the world's commerce," uttered World Relations and Continents ${ }^{48}$ (Toronto, 1911), while a second remarked, "no other continent at all equals Europe in the number and importance of its coastal waters. In addition to their decided affect upon the climate these seas are the scenes of great industries." 49 Canadian School Geography was another 
text that attributed Britain's pre-eminence to "commercial advanages" inherent in its coastal location. ${ }^{50}$ As suggested, mid-century geographers saw commerce carrying religion to the world; later writers, however, hinted its value lay in exchanging ideas, a notion that comes out when discussing the flip-side of Europe's accessibility, the impenetrability of Africa. Dominion School Geography argued, "owing to ... the difficulties encountered in travel [it] is the least progressive and least developed continent," ${ }^{1}$ and World Relations and Continents asked why the ancient civilizations in north Africa "did not lift the veil from Africa south of the desert. The answer is seen in the wonderfully regular coastline," there being "no inlets like Britain to facilitate intercourse." 52

Yet another key natural force shaping human development was climate. Some of the mid-century logic on the effects of climate survived into the 1900s, as was evident in World Relations's praise for the temperate region, "where life must not be one long fight for food, shelter and clothing as it is in the north, nor yet one of idleness as in the warm, hot belt." ${ }^{13}$ But later geographers provided new outlooks on the subject. Public School Geography (Toronto, 1905) disparaged the monotony of the equatorial and polar climates, extolling the temperate zones where the length-of-day "varies," ${ }^{4}$ and World Relations found virtue in the "variety" offered by four seasons. "Surely a home in such a region must be superior." Ansther difference was the language used to describe the effects of climate. At mid-century a moderate climate produced "intelligent and industrious" and "civilized and improved" people, terms not forgotten, but clearly overshadowed by an addition to the later geographer's lexicon, the word "progressive." Russell Hinman observed, "[p]rogress seems to depend upon combinations of favourable conditions far too complex to be followed out. The remarkable fact [is] all high civilization has developed in the north temperate zone..." ${ }^{\text {s6 }}$ Regarding the southern hemisphere, one text found, "the most progressive regions are in the temperate areas of the south," 57 while another surmised, "perhaps on account of its more suitable climate Chile has attracted a large number of Europeans and is more progressive." 88 The word "progressive," itself, had less to do with a state of being than with an ability to change.

One measure of success for a country was the number of people it supported. Traditional belief held a populous nation to be a sign of civilization, large numbers being produced by a co-operative, rational, agrarian lifestyle. Roswell Smith implied this in 1852 when 
he wrote that North America had a "more numerous and intelligent population" than South America." "Later geographers were equally impressed by numbers, to the point of including India in the Caucasian race, but they showed even more interest in population density. The topic commanded space in most textbooks, with one charting human density on a world map. ${ }^{60}$

The theory of population density curned on the ability of a land to support people. High density suggested a physical environment that was favourable for life, a sign that its people were a dominant species variation. As Canadian School Geography maintained, North America's favourable geography "is bound ... to make it the home of a dense population of industrious people." ${ }^{\text {"1 }}$ Dominion School Geography similarly felt the "most progressive nations as well as the densest population of the world" lived on the belt of the temperate forests. ${ }^{62}$

Exceptions to this rule were carefully noted, but usually with a proviso. Public School Geography (Toronto, 1900) described, for example, the Sudan, then a transcontinental belt south of the Sahara, as "very fertile and support[ing] a dense population," but as the Sudanese "worship a multitude of ferishes or idols .., the people are indolent and war-like." ${ }^{63}$ Similarly, High School Geography noted that, although China had a dense population, it was "not progressive," 64 and Dominion School Geography, that the "densely inhabited" eastern nation "refused to adopt new inventions or introduce labour saving machinery."

The concept of density or race propagation was central to Darwin's natural selection theory and, consciously or not, was picked up by geographers in the late nineteenth century. As Greta Jones remarked about the theory, "the species could only be measured against its ability to propagate its kind..." ${ }^{n 6}$ As a result, Dominion School Geographer encouragingly reported, "Europe is the most densely and completely inhabited of all the continents. ${ }^{67}$ Public School Geography added, "although Europe is one of the smallest of the grand divisions it is so thickly settled that Asia only ... exceeds it in population. ${ }^{168}$ Geographers' penchant for density was so widespread that Public School Geography (1905) was the only text to express an obvious contradiction: "the larger numbers of the civilized people live in the country. They are engaged chiefly in agriculture, grazing, mining and lumbering, occupations which cannor be carried out in a densely populated region. ${ }^{169}$ 
The oversight was genuine because food was the means of producing a dense population. Revered by mid-century thinkers for denoting a settled, co-operative existence, in contrast to "barbarous" nomadic ways and "savage" hunting and gathering, agriculture had nevertheless been forced to share center stage with the other pillars of civilization, commerce, and industry. By end of the century agriculture held a place in the public mind far out of proportion to its role in the economy, a fact especially noticeable in commentary on Great Britain. Calling agriculture "the grearest of the arts," World Relations for one reported, the "chief occupations of the people of Great Britain are agriculture, grazing, mining fishing, manufacturing and commerce." Then, jarringly, it added, "now nearly all the wheat comes from abroad." 70 Public School Geography (1900) likewise pointed out English agriculture "is carried on with such skill that larger crops of the leading grains are produced there than anywhere else in the world," but ended with, "the total amount falls far short of the needs of the dense population. "71 Not until the post-war period was the British economy accurately depicted in Canadian geography texts, and even then writers were not fully weaned from the mystique of food production. "While agriculture, mining and fishing are important industries in England," concluded Canadian School Geography in 1922, "she is above all else an industrial and commercial nation."72 Another apparent non-sequiter was Public School Geography's (1905) description of Belgium: "The small kingdom ... has so many large cities that it is one of the most thickly peopled states in the world ... Belgium has been called the 'Garden of Europe.' 73

In Canada's case, textbook authors were not off the mark in stating the importance of agriculture, a fact that only heightened their exuberance for it. "The great industry in Ontario is farming," said High School Geography. Toronto "owes its prosperity ... to those physical conditions that are favourable to commerce ... [and to the fact that it is] accessible to a wide extent of rich farming country." 74 New Canadian Geography (1899) similarly reported, "agriculture holds first place among Canadian industries," "7s and Dominion School Geography, that because of "fertile soil" and a "favourable climate," farming was "the chief Canadian industry." " Despite its elan, few geographers explained why agriculture was so highly esteemed. The best, though not clearest, expression is Dominion School Geography's statement, "the temperate forest region produces a large portion of the food products of the world. Hence the most progressive nations 
... live on the belt of the temperate forests." 77 The inference that home food production out-ranked both commerce and industry in value to a people, suggests the degree to which late Victorians held nature in awe.

The shift from God to nature as master of human destiny decidedly altered the tone of late-nineteenth-century thought. At mid-century, My Little Geography (Philadelphia, 1847) instructed its students that "natural, for instance a natural flower ... [means] that it is just as God made it." ${ }^{\text {"I }}$ Indeed, nature had a fixed quality; description of its endlessly complex forms was a useful addition to knowledge. My Little Geography declared,

The largest cities must decay

And every man must die

But the divisions made by God

Are changeless as the sky. ${ }^{79}$

Nature was proof God existed. "This world is so beautiful," proclaimed My Little Geography. "What do the works of creation plainly show? The wisdom and goodness of the creator," went another. ${ }^{81}$ Soils and minerals existed in abundance, awaiting human exploitation. Harmonizing with nature, of which man was a part, was the end goal.

Surviving under the harsh laws of nature, though, was a vastly different prospect. As Lyell had undermined the concept of an unchanging physical world, Darwin chipped away at the idea that species were inviolable. Darwin conceded a role to geological conditions in the evolutionary process, but survival and change were mainly bound-up in the relationships among living things. Speaking of life generally, he argued,

more individuals are born than can possibly survive... As the individuals of the same species come in all respects into the closest competition with each other, the struggle will generally be the most severe between them; it will be almost equally severe berween varieties of the same species... ${ }^{82}$

Darwin also spoke about the expansion and dominance of some species: "the modified descendents of each species will be enabled to increase by as much as they become more diversified in habits and 
structure, so as to be able to seize on many and widely different places in the economy of nature..." ${ }^{n 3} \mathrm{He}$ found, moreover, that "the more dominant beats the less dominant," and that "the most important of all causes of organic change is ... the mutual relation of organism to organism - the improvement of one organism entailing the improvement or extermination of others. ${ }^{\text {"84 }}$ This was the human geographer's cue to explore the relations between the races. Whereas mid-century writers had believed whites were more civilized and had the responsibility of raising the condition of other races, Darwin plainly stated that they were competing for survival. Survival of the fittest was nature's law. For their part, geographers focused on competition between "varieties of species," or the races, and to a lesser extent on strife between two nations, while completely ignoring struggle at the individual level. This can be partly traced to Darwin's reference in Descent of Man to competition between "tribes" - ones displaying loyalty within the ranks tended to win out. ${ }^{85}$ Nevertheless, by the late 1880 s geographers had let go of the idea that humans were descended from the same parent stock and begun to view the races as being at different stages of evolution.

Russell Hinman delineated the races by hair types, wooly, straight, and wavy, and by the shapes of their heads. Although it was not made explicit, each hair type presumably was tied to a stage of development. As for the head, the most relling feature was the shape of the forehead. Describing the low receding forehead of the African, Hinman noted, "this peculiarity is stronger in some tribes than in others; it is still stronger in the monkey tribes." ${ }^{86}$ Hinman, of course, was borrowing from phrenologists, who looked at head shape to discern the character and intelligence of a person or race, couching phrenology in evolutionary language. By 1910, with phrenology waning, references to head shape disappeared, but skin colour, hair type, and facial features remained important. Dominion School Geography suggested Africans with "short, black kinky hair very broad, flat noses, large round eyes, large teeth and thick lips" still demonstrated characteristics of their animal ancestors. By contrast whites, "the most active, enterprising and intelligent race in the world," had "small mouths and lips, large narrow noses, and straight eyes. ${ }^{87}$

If whites were more evolved, in the minds of text writers, they also demonstrated a greater "power to live." Like "progressive," terms describing the vicality of a people became watchwords of the period. 
Whereas "intelligent," "industrious," and occasionally "robust" dominated at mid-century, later authors spoke of the "vigorous civilization of Western Europe," the "active" white race, the "energy" of the British, and the "not so energetic" Africans. ${ }^{88}$ In a 1922 description of Canada, Canadian School Geography referred to Ontarians as "alert." ${ }^{\text {"9 }}$ Good air was essential for enhancing vicality. Hinman identified respiration as the common process facilitating "development and growth of every organism [as a] ... result of the death and destruction of portions of its protoplasm." 90 One finds in this era rising concern for proper ventilation and a flood of imagery on air quality, such as Geography of the British Colonies' (London, 1895) portrait of the Harmattan winds blowing from the Sahara as a "pestilant breath suck[ing] the life and strength out of the white man."91

"Decay" and "deterioration" were equally keywords of the time, frequently used to describe the condition of a people. Public School Geography (1887) referred to the South American Quichas as "given to intoxication and ... much deteriorated," "92 while the 1900 edition described native south African peoples as "savages in a very degraded state." ${ }^{93}$ Even European lands were scrutinized for this condition, with British Colonies finding the Maltan seaport of Valetta to be a "city of stately but much decayed splendour," and Cyprus, a locale revealing "many evidences of decay."

The corollary of decay and deterioration was the extinction of peoples, a condition that by the late 1800 s was thought to be a natural occurrence. British Colonies argued that South African aboriginal tribes would in all probability have disappeared, even if the white man had not settled in their land, for the "dark race we call Kaffirs and Zulus were pressing them hard upon the north, and slowly exterminating them." 95 It also observed during the nineteenth century "the native races [of Australia] have been slowly disappearing" even though "elaborate pains have been taken to preserve them." 96

Linked to this decline of peoples was the advance of white civilization led by colonists. While most educators displayed some sympathy for the loss of a people, they exhibited cold resignation to this fact. Using Souch Africa again as its model, British Coloniesfound the "Kaffirs, who conquered the land from the aboriginal people ... have themselves been conquered by the whites." 97 World Relations and Continents expressed a similar cone, reminding students that 
"many, many years ago a noble race of invaders, the Aryans ... took possession of the Indus and Ganges Valleys." Meanwhile, Dominion School Geography merely stated, "the white race ... is found in all regions where the climate is favourable for progress." 99

Climate was important to geographers because it spoke to the likelihood of the white race surviving in places such as Africa and the far eastern islands. British Colonies reported that the African shore is "too hot to form the permanent home of Europeans, but the high plateaux have healthy climates and may yet become important settlements for European races." ${ }^{100}$ As for the Malay peninsula, it found "the Europeans [there] unhealthy."101 In essence the text commented on the adaptability of whites to foreign lands. As the white race reproduced in great numbers and were forced to spread out, it was imperative that they find suitable habitats to which to move. A mitigating factor in this process was man's ability to change to adapt to altered conditions, and here Dominion School Geography commended the English people on "their ability to adapt themselves to new conditons in new countries... They always have been progressive..."102

Increasing man's ability to adapt was a strong motive for change in the early twentieth century. Hygenicists exhorted man to develop his mind, and geographers championed "new methods on the farm and in business." 103 "Backwardness" became a synonym for racial decay, and "progressive" the by-word for survival and growth. Since it implied adaptation, the key to survival, change itself was at the heart of the progressive ideology. As people increasingly assumed that they were locked in a struggle for existence, as one text put it, adaprability became a matter of urgency. ${ }^{104}$

In addition to a shift in emphasis, some late-nineteenth and earlytwentieth century textbooks were imbued with a new tone. References to the military strength of nations appear regularly beginning in the 1880s. "As a naval power... [Britain] surpasses all others in the world," reported High School Geography, ${ }^{105}$ while another text declared that "Germany maintains an immense army and a considerable navy." 105 New Canadian Geography (1899) included a section on the Empire, remarking, "British statesmen have shown wisdom in securing control of the leading strategic points of the world." It spoke of Britain's "great battleships," and suggested, "for the purposes of commerce or defence, coal is of great importance." 107 A 1920 British text similarly referred to Dover's "great harbour enclosed by 
massive walls. Yonder is a man o' war and not far away is an Atlantic liner."108

In the nineteenth century the white races were extending "civilization" to the African peoples, but by the twentieth they were coveting their territories. As World Relations observed, "the United Kingdom ... has been able to extend her dominions by purchase, by treaty, by settlement and by conquest." ${ }^{109}$ Referring to the continent it added that "there was trouble in store when so great an area was made known to European nations anxious to extend their lands. The people of Africa were not strong enough to withstand civilized armies..."110 As much as textbook writers softened imperialistic motives, they legitimized the fact that, while missionaries had flocked to Africa in the nineteenth century, conquering armies were the wave of the twentieth.

Carl Berger gendy reminds us "that our own mental outlook, which seems so coherent and final, so free from extravagance, is unlikely to appear that way to posterity." Lill Lewise, early in this century, Canadians, and undoubredly many other nationalities, shaped their world from a mental outlook that now we would call excessive, though not entirely incorrect. Many, if not most, people roday believe we share common a common ancestry with the lower primates. The difference between contemporary thinkers and the late Victorians is that the latter never seemed to understand that evolution is played out at a glacial pace, at least the human part of it. Darwin was explicit in this regard, but his prose does brim with an energy that makes biological change appear to take place almost before our eyes. A hard-working, earnest lot, that hankered after universal truchs, Victorians were quick to get to the meat of an idea, and then run with it. Compared to natural theology, Darwinism was a dark philosophy that put humankind on the treadmill of change simply to stay alive. It lionized food production, championed large populations, and spurred on education. As well, it exacerbated racial and national rensions and made a necessity of imperialistic wars. More than a scientific discovery, Darwinism became a way of thinking. 


\section{NOTES}

Acknowledgement: While any errors in fact and interpretation are mine alone, I wish to thank Chris Hackett, Philip Massolin, Doug Owram, and the two anonymous referees for their valuable comments and suggestions of ways to improve this paper.

' Carl Berger, Science, God, and Nature in Victorian Canada(Toronto, 1983), 53

${ }^{2}$ Ramsay Cook, The Regenerators, Social Criticism in Late Victorian Canada (Toronto, 1985)

${ }^{3}$ S. Augustus Mitchell, $A$ System of Modern Geography Comprising a Present State of the World (Philadelphia, 1852), 6

${ }^{4} \mathrm{Karl}$ Grove Gilbert and Albert Perry Brigham, Ontario High School Physical Geography (Toronto, 1914), 15

${ }^{5}$ N.A., Dominion School Geography (Toronto, 1910), 7

${ }^{6}$ Alison Prentice, The School Promoters (Toronto, 1977), 80

${ }^{7}$ Bruce Curtis, Building the Educational State: Canada West, 18361871 (London, Ontario, 1988), 279

${ }^{8} \mathrm{~F}$. Henry Johnson, $A$ History of Education in British Columbia (Vancouver, 1964), 59; Bernal E. Walker, "The High School Program in Alberta during the Territorial Period, $1889-1905$," in Shaping the Schools of the Canadian West, eds. David C. Jones et. al. (Calgary, 1979), 219

'Ibid., 216

${ }^{10}$ Bernard Amtmann, A Bibliography of Canadian Children's Books and Books for Young People, 1841 - 1867 (Montreal, 1977)

"Curtis, Building the Educational State, 268

12 Textbooks used in this study are part of the Curriculum History Collection of the Herbert T. Coutts Library at the University of Alberca.

${ }^{13}$ A.B. McKillop, A Disciplined Intelligence, Critical Inquiry and Canadian Thought in the Victorian Era (Montreal, 1979), 63

${ }^{14}$ Curtis, Building the Educational State, 267

is Charles R. Dryer, "A century of geographic education in the United Staces," Annals of the Association of American Geographers, $14: 3$ (1924), 119

${ }^{16}$ Ibid., 130

${ }^{17}$ Roswell C. Smith, An Introductory Geography Designed for Children (New York, 1852), opposite title page; James Monteith, Monteith's 
First Lessons in Geography (New York, 1873), 11

${ }^{18}$ L.C. Tuthill, ed., My Little Geography (Philadelphia, 1847), 86; William Channing Woodbridge, A System of Universal Geography on the Principles of Comparison and Classification (Hartford, 1827), 39 ${ }^{19}$ William Stanton, The Leopard's Spots: Scientific Attitudes Toward Race in America, $1815-1859$ (Chicago, 1960). For a summary of competing views on whether or not humankind consisted of one or "various species of men," see pages $15-23$.

${ }^{20}$ Mitchell, $A$ System of Modern Geography, 40

${ }^{21}$ S.S. Cornell, Cornell's High School Geography (New York, 1857), 164

${ }^{22}$ S. Augustus Mitchell, New School Geography (Philadelphia, 1878), 35,222

${ }^{23}$ Cornell, Cornell's High School Geography, 13

${ }^{24}$ William Swinton, Introductory Geography in Readings and Recitations (New York, 1882), 19

${ }^{25}$ Smith, Smith's First Book, 146

${ }^{26}$ Mitchell, $A$ System of Modern Geography, 48

${ }^{27}$ Mitchell, New School Geography, 416

${ }^{28}$ Smith, Smith's First Book, 146

${ }^{29}$ N.A., The Public School Geography (Toronto, 1887), 153

${ }^{30}$ G.A. Chase, High School Geography (Toronto, 1887), 179

${ }^{31}$ Ibid., 179, 146

${ }^{32}$ Ibid., 4

${ }^{33}$ Russell Hinman, Eclectic Physical Geography (New York, 1888), 354

${ }^{34}$ Dryer, "A century of geographic education," 132

${ }^{35}$ Hinman, Eclectic Physical Geography, 372

${ }^{36}$ Ibid., 7

${ }^{37}$ Gilbert, Ontario High School Physical Geography, 14

${ }^{38}$ Dryer, "A century of geographic education," 133

${ }^{39}$ Charles Darwin, The Origin of Species (New York: W.W. Nation \& Co., 1975), 107. This is an abridged version of the sixth edition published in 1872.

${ }^{40}$ J.A. Campbell and D.N. Livingstone, "Neo-Lamarckism and the development of geography in the United States and Great Britain," Transactions, Institute of British Geographers 8 (1983), 271 ${ }^{41}$ N.A., The Public School Geography (Toronto, 1900), 3 ${ }^{42}$ N.A., Dominion School Geography (Toronto, 1910), 41 ${ }^{43}$ Chase, High School Geography, 67 
${ }^{44}$ Dominion School Geography, 193, 209

45 Alexander Mclntyre, World Relations and Continents (Toronto, 1911), 121

${ }^{46}$ George A. Cornish, Canadian School Geography (Toronto, 1922), 212

${ }^{47}$ Hinman, Eclectic Physical Geography, 372

${ }^{48}$ McIntyre, World Relations, 82

${ }^{49}$ Chase, High School Geography, 149

so Cornish, Canadian School Geography, 308

${ }^{51}$ Dominion School Geography, 244

52 McIntyre, World Relations, 163

53 Ibid., 34

${ }^{54}$ N.A., The Public School Geography (Toronto, 1905), 25

ss McIntyre, World Relations, 34

${ }^{56}$ Hinman, Eclectic Physical Geography, 364

"7 Dominion School Geography, 244

${ }^{58}$ Cornish, Canadian School Geography, 297

"s9 Smith, Smith's First Book, 55

${ }^{60}$ Dominion School Geography, 55

${ }^{61}$ Cornish, Canadian School Geography, 136

${ }^{62}$ Dominion School Geography, 5

${ }^{63}$ The Public School Geography (1900), 157

${ }^{64}$ Chase, High School Geography, 178

"s Dominion School Geography, 230

${ }^{66}$ Greta Jones, Social Darwinism and English Thought (Sussex, 1980), 7

${ }^{67}$ Dominion School Geography, 187

${ }^{68}$ The Public School Geography (1900), 119

${ }^{69}$ The Public School Geography (1905), 62

${ }^{70}$ McIntyre, World Relations, 94

71 The Public School Geography (1900), 127

${ }^{72}$ Cornish, Canadian School Geography, 320

${ }^{73}$ The Public School Geography (1905), 133

${ }^{74}$ Chase, High School Geography, 73

75 N.A., New Canadian Geography (Toronto, 1899), 76

${ }^{76}$ Dominion School Geography, 92

77 Ibid., 53

${ }^{78}$ Tuthill, My Little Geography, 74

${ }^{79}$ Ibid., 75

${ }^{80}$ Ibid., 137 
${ }^{81}$ Smith, Smith's First Book, 9

${ }^{82}$ Darwin, Origins, 106

83 Ibid., 81

${ }^{84}$ Ibid., 122

${ }^{85}$ Jones, Social Darwinism, 39, 40

${ }^{86}$ Hinman, Eclectic Physical Geography, 359

${ }^{87}$ Dominion School Geography, 60, 62

88 Ibid., 60, 187

${ }^{89}$ Cornish, Canadian School Geography, 212

${ }^{90}$ Hinman, Eclectic Physical Geography, 316

${ }^{11}$ George M. Dawson and Alexander Sutherland, Geography of the British Colonies (London, 1895), 219. This work was authorized for use in the North West Territories. See 217 n 9.

${ }_{92}$ The Public School Geography (1887), 91

${ }^{93}$ The Public School Geography (1900), 154

${ }^{94}$ Dawson, British Colonies, 188, 189

95 Ibid., 204

96 Ibid., 24

97 Ibid., 204

${ }^{98}$ McIntyre, World Relations, 155

99 Dominion School Geography, 60

${ }^{100}$ Dawson, British Colonies, 204

101 Ibid., 237

102 Dominion School Geography, 191

${ }^{103}$ Cornish, Canadian School Geography, 193

${ }^{104}$ Gilbert, Ontario High School Physical Geography, 77

${ }^{105}$ Chase, High School Geography, 155

106 The Public School Geography (1887), 118

${ }^{107}$ New Canadian Geography, 208, 209

${ }^{108}$ Hillaire Belloc, The Highroads of Geography, The Royal School Series Book IV, The Continent of Europe (London, 1920), 37

${ }^{109}$ McIntyre, World Relations, 92

110 Ibid., 153

111 Carl Berger, The Sense of Power: Studies in the Ideas of Canadian Imperialism, 1867 - 1914 (Toronto, 1970), 265 